\title{
Characterization of fatty acid, antioxidant, and polyphenol content of grape seed oil from different Vitis vinifera L. varieties ${ }^{\text {is }}$
}

\author{
Viktória Kapcsándi, Erika Hanczné Lakatos, Beatrix Sik, László Ádám Linka and Rita Székelyhidi* \\ Department of Food Science, Faculty of Agricultural and Food Sciences, Széchenyi István University, Lucsony street 15-17, 9200 \\ Mosonmagyaróvár, Hungary
}

Received 8 January 2021 - Accepted 16 April 2021

\begin{abstract}
In this study, we examined the yield and oil quality of eight different grape varieties. For the experiments, the grape seeds were obtained from the Benedictine Pannonhalma Archabbey in the northwestern region of Hungary. The aim of the studies was to determine the oil yield obtained by extraction and to examine the differences between the fatty acid composition, antioxidant capacity, and total polyphenol content of the oils of different grape varieties. Based on the results, the oil content of the grape seeds varied between $99.91 \mathrm{~g} / \mathrm{kg}$ and $126.74 \mathrm{~g} / \mathrm{kg}$. The grape seed oils analysed contained significant amounts of stearic acid (3.42-9.93\%), palmitic acid (7.81-10.66\%), oleic acid (14.29-19.92\%), and linoleic acid (66.85-72.47\%). Besides, the grape seed oils tested contained several other fatty acids in small amounts. There were significant differences in the total antioxidant and total polyphenol content of the oils. Total polyphenol content ranged from 0.24 to $1.13 \mathrm{mg} \mathrm{GAE} / \mathrm{g}$, while the total antioxidant content changed between 0.12 and $0.78 \mu \mathrm{g} \mathrm{TEAC/g}$. The results show that the studied varieties are suitable for the production of table grape seed oil based on their oil yield, and the oils have favourable, health-protecting properties in terms of their quality.
\end{abstract}

Keywords: grape seed oil / oil yield / fatty acid composition / polyphenols / antioxidants

\begin{abstract}
Résumé - Caractérisation de la teneur en acides gras, en antioxydants et en polyphénols de l'huile de pépins de raisin de différentes variétés de Vitis vinifera L.. Dans cette étude, nous avons examiné le rendement et la qualité de l'huile de huit différentes variétés de raisin. Pour les expériences, les pépins de raisin ont été obtenus de l'abbaye bénédictine de Pannonhalma dans le Nord-Ouest de la Hongrie. L'objectif était de déterminer le rendement en huile obtenu par extraction et d'examiner les différences de composition en acides gras, capacité antioxydante et teneur totale en polyphénols des huiles issues de différents cépages. D'après les résultats, la teneur en huile des pépins de raisin variait entre $99,91 \mathrm{~g} / \mathrm{kg}$ et $126,74 \mathrm{~g} / \mathrm{kg}$. Les huiles de pépins de raisin analysées contenaient des quantités significatives d'acide stéarique $(3,42-9,93 \%)$, d'acide palmitique (7,81-10,66\%), d'acide oléique (14,29-19,92\%) et d'acide linoléique $(66,85-72,47 \%)$. En outre, les huiles de pépins de raisin testées contenaient plusieurs autres acides gras en petites quantités. Des différences significatives dans la teneur en antioxydants totaux et en polyphénols totaux des huiles ont été notées: la teneur en polyphénols totaux variait de 0,24 à $1,13 \mathrm{mg} \mathrm{GAE} / \mathrm{g}$, tandis que la teneur en antioxydants totaux variait de 0,12 à $0,78 \mu \mathrm{g}$ TEAC/g. Les résultats montrent que les variétés étudiées conviennent à la production d'huile de table issue de pépins de raisin au regard de leur rendement en huile, et que, sur le plan qualitatif, les huiles possèdent des propriétés bénéfiques et protectrices sur la santé.
\end{abstract}

Mots clés : huile de pépins de raisin / rendement en huile / composition en acides gras / polyphénols / antioxydants

\footnotetext{
"Contribution to the Topical Issue "Minor oils from atypical plant sources / Huiles mineures de sources végétales atypiques".

*Correspondence: szekelyhidi.rita@sze.hu
} 


\section{Introduction}

Grape (Vitis vinifera L.) is one of the most widely grown fruit in the world. Nearly 80 million tons of grapes are harvested annually (OIV, 2019). Much of this is consumed in the form of fresh fruit, juice or raisins. The other part of the harvested grapes is used for winemaking, it also shows that wine is one of the most popular alcoholic beverages (Kallithraka et al., 2006; Teixeira et al., 2014). The most important wine regions are in Europe(Italy, Spain, France, Germany and Portugal), North and South America(United States, Argentina, Chile) Asia (China) (OIV, 2019), Australia and South Africa. However, the cultivation and processing of grapes also involves the production of large quantities of byproducts such as grape marc, grape seed, grape skin, grape stem and grape leaf. Most of these by-products contain large amounts of physiologically important phenolic compounds. Grape marc is the main by-product that remains after pressing; which is about $20 \%$ of all grapes processed in wineries (Goula et al., 2016; Bordiga et al., 2019). Grape marc is a basic byproduct of wine production, which also includes 20-26\% grape seed with the valuable oil and proteins it contains (Mattos et al., 2017). Thirty-five thousand tonnes of grape seed oil are produced worldwide each year, of which 10000 tonnes come from French factories (Pierron, 2017).

The grapes should ideally contain 4 seeds, which are formed from the four seed buds in the seed coat. In exceptional cases, more seeds may be formed, but usually less than four seeds are typical, $13 \%$ of the total weight of grapes is grape seed. The complete absence of seeds can be a characteristic of the grape variety, this is an ideal property in the case of table grapes and raisins. The nutrition of grape seed is physiologically important as it contains roughly $32-43 \mathrm{~m} / \mathrm{m} \%$ dietary fiber, $7-17 \mathrm{~m} / \mathrm{m} \%$ protein and about $5-8 \mathrm{~m} / \mathrm{m} \%$ complex phenolic compound, as well as sugars, mineral salts, etc. (Fantozzi, 1981; Shi et al., 2003; Campos et al., 2008; Tangolar et al., 2009; Mattos et al., 2017).

In addition, grape seeds contain $8-20 \%$ oil, which is rich in essential fatty acids. The amount of oil that can be extracted depends on the grape variety and the extraction process used (Bail et al., 2008). The chemical composition of the extracted oil is influenced by the degree of ripeness and species of the seeds, the environmental parameters, the cultivation works and to a small extent the seed extraction protocol (Shinagawa et al., 2015; Garavaglia et al., 2016; Martin et al., 2020). Despite these factors, unlike grapes, grape seeds and their extracts, especially grape seed oil, contain large amounts of lipophilic molecules, among which are several important biocomponents.

The most common of these molecules are fatty acids. In general, about $90 \%$ of the total amount of grapeseed oil is mono- and polysaturated fatty acids. It contains in the highest amount of linoleic acid (58-78\%), oleic acid (3-15\%), and to a lesser extent other saturated fatty acids (10\%) (Bail et al., 2008; Rombaut et al., 2015; Konuskan et al., 2019).

The second largest group of lipophilic molecules in grape seeds are vitamins. Phytosterols are also important lipophilic molecules in grape seed oil, but their amount is influenced by harvest conditions and oil extraction methods. The biological importance of phytosterols lies in their antioxidant activity and their role in cholesterol metabolism (Shinagawa et al., 2015; Garavaglia et al., 2016).

Phenols are natural molecules with antioxidant effects and are present in grapes, especially in grape seeds and their extracts. However, hydrophilic phenols make up only a small proportion of grape seed oil (Fernandes et al., 2013; Khurana et al., 2013), but properly selected oil extraction processes can increase the phenol content of oils (Maier et al., 2009; Rombaut et al., 2015). Among the phenolic compounds, grape seed oil contains mainly gallic acid, catechin, epicatechin, procyanidins and proanthocyanidins or condensed tannins, which are known for their antioxidant activity (Garavaglia et al., 2016).

In this study, grape seed oil was produced from eight different grape varieties using Soxhlet extraction, which was grown in the northwestern region of Hungary by the Benedictine Archabbey of Pannonhalma. The aim of the studies was to determine the oil yield obtained by solvent extraction and to investigate the differences between the fatty acid composition, antioxidant capacity and total polyphenol content of the oils of different grape varieties.

\section{Materials and methods}

\subsection{Grape seed samples}

The dried grape seed samples with a moisture content of $7-8 \%$ (on a dry matter basis) were obtained from the Benedictine Pannonhalma Archabbey (Hungary). The studied varieties were the following: "Italian Riesling", "Cabernet Franc", "Pinot Noir", "Sauvignon Blanc", "Királyleányka", "Rhine Riesling", "Merlot", and "Lemberger". The dried samples were chopped using a coffee grinder(Sencor, SCG 2050RD) and stored away from light until analysis.

\subsection{Chemicals}

Petroleum ether (Carlo Erba, Spain) boiling at $40-70{ }^{\circ} \mathrm{C}$ was used for Soxhlet extraction. Sodium hydroxide, sodium chloride, n-hexane, boron-trifluoride in methanol were purchased from Merck(Germany) to determine fatty acid composition. Supelco 37 FAME Mix (Sigma-Aldrich, USA) was used to identify fatty acids. Chemicals for the determination of polyphenol and antioxidant content were $97 \%$ ethanol(Reanal, Hungary), anhydrous sodium carbonate (Riedel-de Haën, Germany), Folin-Ciocalteu reagent (Merck, Germany), 2-4-6-tripyridyl-s-triazine (TPTZ) (Sigma-Aldrich, Hungary), acetic acid(Reanal, Hungary), anhydrous iron chloride (Merck, Germany), 98\% Trolox (Sigma-Aldrich, Hungary), gallic acid (Sigma-Aldrich, Hungary). Nitrogen (4.6) and helium (5.0) was purchased from Linde(Hungary).

\subsection{Oil extraction from grape seeds}

\subsubsection{Soxhlet-extraction}

The milled grape seeds $(10 \mathrm{~g})$ were extracted with $170 \mathrm{~mL}$ petroleum ether for $3 \mathrm{~h}$ at a maximum temperature of $70{ }^{\circ} \mathrm{C}$ in a Soxhlet apparatus. After extraction was completed, petroleum ether was evaporated by a rotary evaporator (Bibby, RE 100). 
The oils obtained were weighed and the yields were calculated. Grape seed oils were weighed into $4 \mathrm{~mL}$ screw cap vials and stored in an ultra-freezer at $-55^{\circ} \mathrm{C}$ for further analysis.

\subsection{GC-MS method}

\subsubsection{Sample preparation}

Six $\mathrm{mL}$ of $0.5 \mathrm{M} \mathrm{NaOH}$ was added into a round bottom flask containing $25 \mathrm{mg}$ grape seed oil. Samples were extracted for $6 \mathrm{~min}$ at $70^{\circ} \mathrm{C}$ using a laboratory water bath equipment. After the oil droplets had dissolved, the solution was heated with $70 \mathrm{~mL}$ of boron trifluoride in methanol $(14 \%)$ for 2.5 minutes at $70^{\circ} \mathrm{C}$. Finally, $4 \mathrm{~mL}$ n-hexane and $6 \mathrm{~mL}$ saturated $\mathrm{NaCl}$ solution were added and vortexed. For analysis, the methyl-esterified sample was taken from the upper hexane phase, which was first removed and concentrated under nitrogen.

\subsubsection{GC-MS analysis}

For the determination of fatty acid composition of the oils a Shimadzu (Kyoto, Japan) GCMS-QP2010 SE type equipment was used. Fatty acids were separated on a Zebron BPX-70 $(30 \mathrm{~m} \times 0.25 \mathrm{~mm} \times 0.25 \mu \mathrm{m})$ column (Phenomenex, USA). The applied temperature program was $60^{\circ} \mathrm{C}-120^{\circ} \mathrm{C}$ with a heating rate of $13{ }^{\circ} \mathrm{C} / \mathrm{min}$, then $120^{\circ} \mathrm{C}-240^{\circ} \mathrm{C}$ with a heating rate of $2{ }^{\circ} \mathrm{C} / \mathrm{min}$, and finally $240^{\circ} \mathrm{C}$ for 8 minutes. One $\mu \mathrm{L}$ of sample solutions was transferred to the $220^{\circ} \mathrm{C}$ injector of the GC-MS in split mode (split ratio 40). Helium was used as carrier gas with a linear flow rate $(1 \mathrm{~mL} / \mathrm{min})$.

\subsection{Determination of total antioxidant and polyphenol content}

\subsubsection{Sample preparation}

To determine the antioxidant and polyphenol content, grape seed oils were extracted by solvent extraction technique as follows. Briefly, a mass of $1 \mathrm{~g}$ of oil was extracted with $5 \mathrm{~mL}$ of ethanol/water $(70: 30 \mathrm{v} / \mathrm{v} \%)$ at $60^{\circ} \mathrm{C}$ for $5 \mathrm{~min}$ by means of an RF-120F ultrasonic bath (Realsonic, Hungary). The oily extracts were filtered through a filter paper, and the filtrate was used for further analysis.

\subsubsection{FRAP assay}

Two hundred $\mu \mathrm{L}$ of extracted sample, $3 \mathrm{~mL}$ of FRAP solution, and $100 \mu \mathrm{L}$ of water were pipetted into a test tube. The finished solutions were placed in a dark place for $5 \mathrm{~min}$ and then their absorbance was measured with a Spectroquant Pharo 100 spectrophotometer (Merck, Germany) at a wavelength of $593 \mathrm{~nm}$ against the blank. Trolox was used as a standard $(1-30 \mathrm{ug} / \mathrm{mL})$ and the results were expressed as ug Trolox equivalent antioxidant capacity (TEAC)/g oil.

\subsubsection{Folin-Ciocalteu assay}

To $200 \mu \mathrm{L}$ of grape seed oil extract, $1.5 \mathrm{~mL}$ of high purity water was pipetted and the reagents were added. First $2.5 \mathrm{~mL}$ of $10 \%$ Folin-Ciocalteu reagent, then $2 \mathrm{~mL}$ of $7.5 \% \mathrm{Na}_{2} \mathrm{CO}_{3}$. The test tubes containing the mixture were placed in a dark place for $90 \mathrm{~min}$, and then the absorbance was measured at

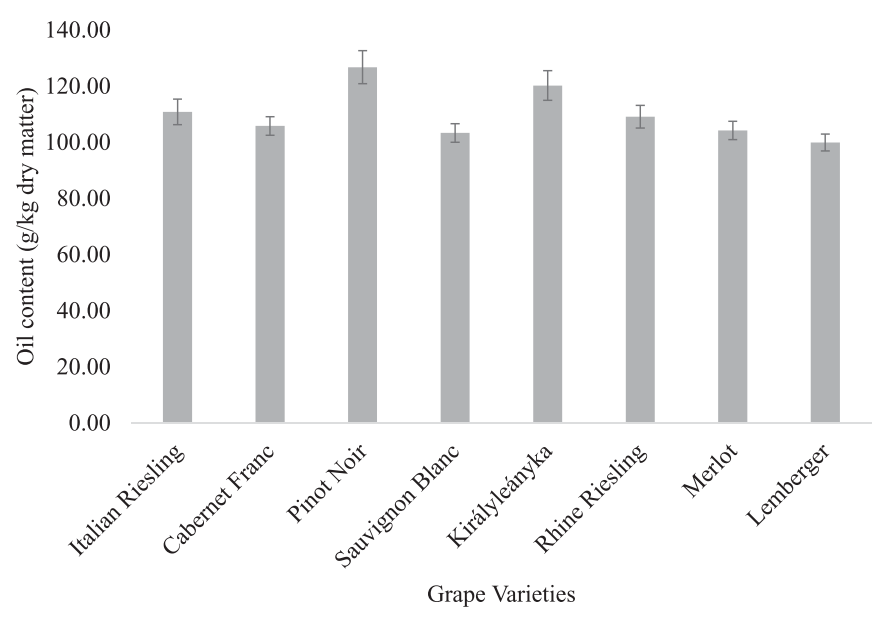

Fig. 1. Oil yield of grape seeds of different cultivars $(\mathrm{g} / \mathrm{kg})$.

$725 \mathrm{~nm}$ versus the blank. Gallic acid was used as a standard $(25-100 \mathrm{mg} / \mathrm{mL})$.

\subsubsection{Data analysis}

The total antioxidant and polyphenol contents of grape seed oils were determined in Microsoft Office Excel from the absorbance values measured for grape seed oils using the equation of the second-order least squares analytical curve fitted to the measurement solutions using the nonlinear leastsquares method. All the results are expressed as means $(n=3) \pm$ standard deviation.

\section{Results and discussion}

\subsection{Oil yield}

During the Soxhlet extraction, the oil content of each grape seed sample was determined gravimetrically. During the evaluation, we present our results in terms of $\mathrm{g} / \mathrm{kg}$ dry matter (Fig. 1).

As shown in Figure 1, the grape seed cultivars we studied provided similar results in oil yield. Significant differences were found, the difference between the highest and lowest oil yield was $26.83 \mathrm{~g} / \mathrm{kg}$ dry matter. The highest amount of oil was extracted from "Pinot Noir" $(126.74 \mathrm{~g} / \mathrm{kg})$ and the lowest amount from "Lemberger" $(99.91 \mathrm{~g} / \mathrm{kg})$ grape seed meal.

Among grape varieties, seeds of Sauvignon Blanc showed the lowest percentage yield $(10.33 \%)$, while the oil yield from "Pinot Noir" was the highest(12.67\%). "Királyleányka" contained the second-highest yield of oil(12.02\%), followed by "Italian Riesling" (11.08\%), Rhine Riesling (10.91\%), "Cabernet Franc"(10.58\%), and "Merlot" (10.47\%). These oil yields correspond to the $8-20 \%$ oil content reported in the literature (Crews et al., 2006; Bail et al., 2008; Tangolar et al., 2009; Sabir et al., 2012; Elagamey et al., 2013; Fernandes et al., 2013; Lachman et al., 2015), and similar oil yields were observed for the same grape seed samples under industrial conditions.

\subsection{Fatty acid composition of grape seed oils}

Grape seed oil is rich in polyunsaturated fatty acids. The fatty acid composition of the 8 types of grape seed oil tested is 


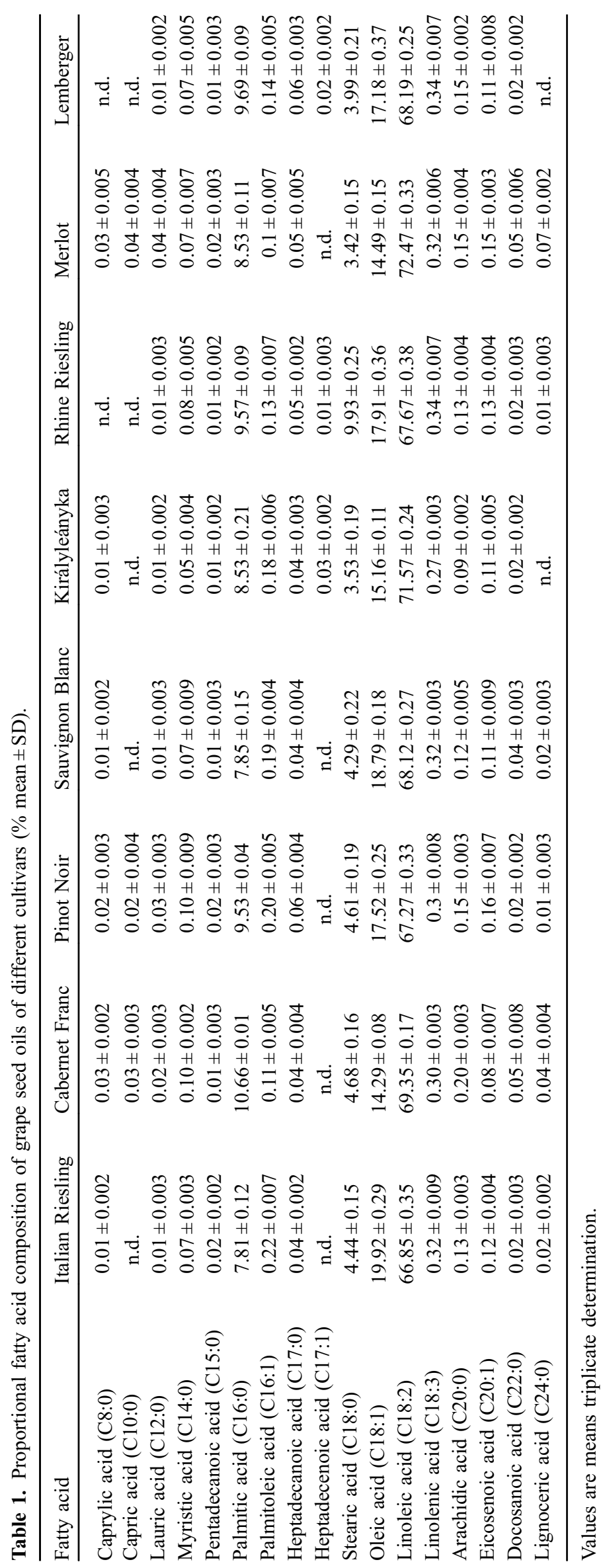




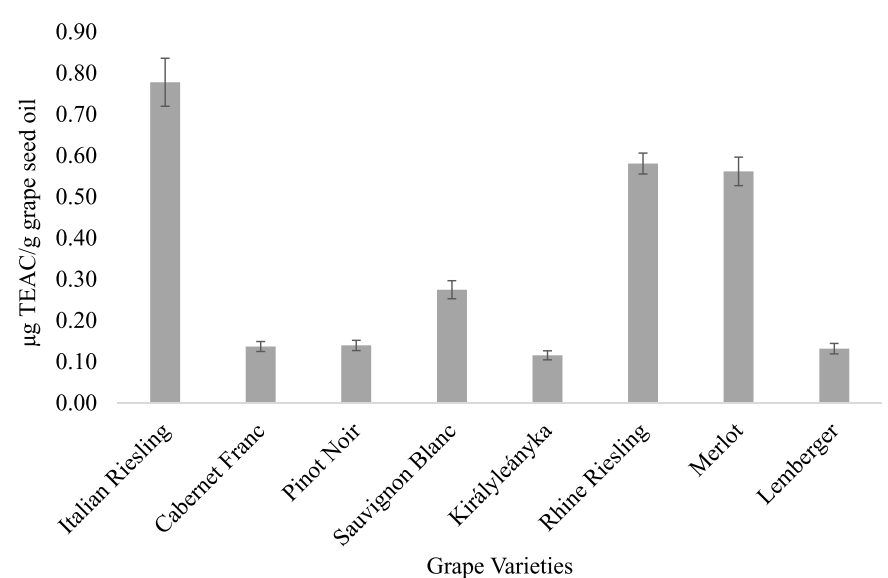

Fig. 2. Antioxidant content of grape seed oils of different cultivars.

shown in Table 1. For all cultivars, the major fatty acids were stearic acid (C18:0), palmitic acid (C16:0), oleic acid(C18:1), and linoleic acid (C12:2). Linoleic acid was the most abundant fatty acid in all samples, contributing between $66.8 \%$ and $72.47 \%$ of total fatty acids. The Italian Riesling seeds had the lowest content of linoleic acid (66.85\%), with "Merlot" containing the highest amount of $72.47 \%$. The next fatty acid in the row is oleic acid, ranging from $14.29 \%$ (Cabernet Franc) to $19.92 \%$ (Italian Riesling). The seeds also contained significant palmitic acid. The smallest amount was detected in "Italian Riesling" $(7.81 \%)$ and the highest amount in "Cabernet Franc"(10.66\%). Grape seed oil samples still contained small but significant amounts of stearic acid, the smallest amount of "Merlot" (3.42\%), and the largest amount of "Rhine Riesling" $(9.93 \%)$ contained among the examined grape varieties. The minor fatty acids included caprylic acid, capric acid, lauric acid, myristic acid, pentadecanoic acid, palmitoleic acid, heptadecanoic acid, heptadecenoic acid, linolenic acid, arachidic acid, eicosenoic acid, docosanoic acid, land ignoceric acid (all at $<0.3 \%$ ) We found significant differences in the fatty acid composition of the oils of each grape variety, a finding supported by several studies (Beveridge et al., 2005; Crews et al., 2006; Pardo et al., 2009; Sabir et al., 2012; Konuskan et al., 2019).

\subsection{Antioxidant content of grape seed oils}

The antioxidant content of grape seed oils was evaluated using FRAP assay (Fig. 2). Based on the results, it can be stated that the examined grape seed oils showed significant differences. "Italian Riesling" $(0.78 \mu \mathrm{g}$ TEAC/g $)$ had the highest amount of antioxidants, followed by "Rhine Riesling" $(0.58 \mu \mathrm{g}$ TEAC/g), "Merlot" $(0.56 \mu \mathrm{g}$ TEAC/g), and "Sauvignon Blanc" $(0.27 \mu \mathrm{g}$ TEAC/g). As shown in Figure 2, we did not find significant difference between "Rhine Riesling" and "Merlot". Similar tendency was observed for "Cabernet Franc" $(0.14 \mu \mathrm{g}$ TEAC/g), "Pinot Noir" $(0.14 \mu \mathrm{g}$ TEAC/g), "Királyleányka" $(0.12 \mu \mathrm{g}$ TEAC/g), and "Lemberger" (0.13 $\mu \mathrm{g} \mathrm{TEAC/g}$ ) (Fig. 2).

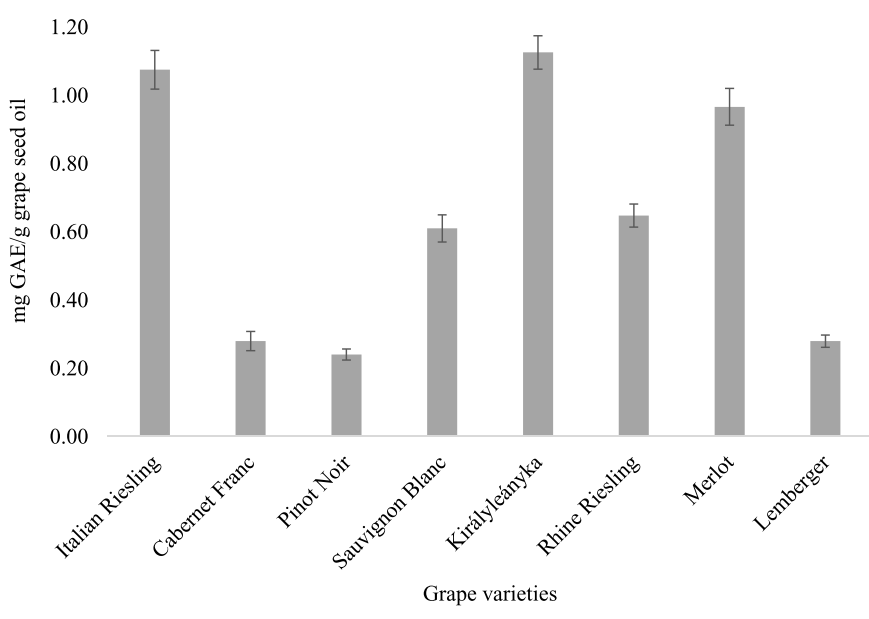

Fig. 3. Phenolic content of grape seed oils of different cultivars.

\subsection{Polyphenol content of grape seed oils}

Phenolic compounds are poorly soluble in the oily phases, but small amounts are transferred to the oil from the solid matrix during extraction. The method used was able to detect polyphenols from all types of grape seed oil.

The total polyphenol contents of the grape seed oils are shown in Figure 3. Large differences in the total polyphenol content of each grape seed oil variety were observed. The total polyphenol values of the grape seed oils renged from 0.24 to $1.13 \mathrm{mgGAE} / \mathrm{g}$. The highest polyphenol content was measured for the "Királyleányka" (1.13 mg GAE/g), followed by "Italian Riesling" (1.08 mg GAE/g), "Merlot" (0.97 mg GAE/g), "Rhine Riesling" (0.65 mg GAE/g), "Sauvignon Blanc" (0.61 mg GAE/g), "Cabernet Franc" $0.28 \mathrm{mg} \mathrm{GAE} / \mathrm{g})$, "Lemberger" (0.28 mg GAE/g), and "Pinot Noir" (0.24 mg GAE/g).

\section{Conclusion}

The oil yields of the studied grape varieties showed significant differences and ranged from 9 to $13 \%$. These values fit into the $8-20 \%$ oil yields reported in the literature. The fatty acid composition of eight different grape seed oils was determined by GC-MS. As shown by the results obtained, the fatty acid profile of oils was similar. In spite of this, sometimes, we found a significant difference between the fatty acid content of different grape varieties. Our study also revealed that the total polyphenol and antioxidant content of grape seed oil is much lower than that of grape seed, but its consumption can still have a beneficial effect on human health. Our result supported that the analyzed grape varieties are suitable for the production of edible grape seed oil. It is important to note that if we want to press oil under industrial conditions from grape seeds for consumption, we need a large amount of grape seed. In addition to the $8-20 \%$ oil yield mentioned in the literature, that means $5-13 \mathrm{~kg}$ of dried grape seeds are required to produce 1 liter of grape seed oil. 


\section{Conflict of interest}

The authors have declared no conflict of interest.

Acknowledgement. Supported by the ÚNKP-20-4-II New National Excellence Program of the Ministry for Innovation and Technology from the source of the National Research, Development and Innovation Fund.

\section{References}

Bail S, Stuebiger G, Krist S, Unterweger H, Buchbauer G. 2008. Characterization of various grape seed oils by volatile compounds, triacylglycerol composition, total phenols and antioxidant capacity. Food Chem 108(3): 1122-32.

Beveridge THJ, Girard B, Kopp T, Drover JCG. 2005. Yield and composition of grape seed oils extracted by supercritical carbon dioxide and petroleum ether: varietal effects. J Agr Food Chem 53 (5): 1799-1804.

Bordiga M, Travaglia F, Locatelli M. 2019. Valorisation of grape pomace: An approach that is increasingly reaching its maturity a review. Int J Food Sci Technol 54(4): 933-942.

Campos LMAS, Leimann FV, Pedrosa RC, Ferreira SRS. 2008. Free radical scavenging of grape pomace extracts from Cabernet Sauvignon (Vitis vinifera). Bioresour Technol 99: 8413-8420.

Crews C, Hough P, Godward J, Brereton P, Lees M, Guiet S, Winkelmann W. 2006. Quantitation of the main constituents of some authentic grape-seed oils of different origin. J Agr Food Chem 54: 6261-6265.

Elagamey AA, Abdel-Wahab MA, Shimaa MME, Abdel-Mogib M. 2013. Comparative study of morphological characteristics and chemical constituents of seeds of some grape table varieties. $\mathrm{J} \mathrm{Am}$ Sci 9: 447-454.

Fantozzi P. 1981. Grape seed: a potential source of protein. JAOCS 58: $1027-1031$

Fernandes L, Casal S, Cruz R, Pereira JA, Ramalhosa E. 2013. Seed oils of ten traditional Portuguese grape varieties with interesting chemical and antioxidant properties. Food Res Int 50: 161-166.

Garavaglia J, Markoski MM, Oliveira A, Marcadenti A. 2016. Grape seed oil compounds: biological and chemical actions for health. Nutr Metab Insights 9: 59-64.

Goula AM, Thymiatis K, Kaderides K. 2016. Valorization of grape pomace: drying behavior and ultrasound extraction of phenolics. Food Bioprod Process 100(Part A): 132-144.

International Organisation of Vine and Wine (OIV). 2019. Statistical Report on World Vitiviniculture. Available online: http://oiv.int/ public/medias/6782/oiv-2019-statistical-report-on-world-vitivini culture.pdf.
Kallithraka S, Tsoutsouras E, Tzourou E, Lanaridis P. 2006. Principal phenolic compounds in Greek red wines. Food Chem 99: 784-93.

Khurana S, Venkataraman K, Hollingsworth A, Piche M, Tai TC. 2013. Polyphenols: benefits to the cardiovascular system in health and in aging. Nutrients 5: 3779-3827.

Konuskan DB, Kamiloglu O, Demirkeser ÖK. 2019. Fatty acid composition, total phenolic content and antioxidant activity of grape seed oils obtained by cold-pressed and solvent extraction. Indian J Pharm Educ 53: 144-150.

Lachman J, Hejtmánková A, Táborský J, et al. 2015. Evaluation of oil content and fatty acid composition in the seed of grapevine varieties. LWT Food Sci Technol 63: 620-625.

Maier T, Schieber A, Kammerer DR, Carle R. 2009. Residues of grape (Vitis vinifera $\mathrm{L}$.) seed oil production as a valuable source of phenolic antioxidants. Food Chem 112: 551-559.

Martin ME, Grao-Cruces E, Millan-Linares MC, Montserrat-de la Paz S. 2020. Grape (Vitis vinifera L.) seed oil: a functional food from the winemaking industry. Foods 9(10): 1360.

Mattos GN, Tonon RV, Furtado AAL, Cabral LMC. 2017. Grape byproduct extracts against microbial proliferation and lipid oxidation: a review. J Sci Food Agric 97: 1055-64.

Mattos GN, Tonon RV, Furtado AAL, Cabral LMC. 2017. Grape by-product extracts against microbial proliferation and lipid oxidation: a review. J Sci Food Agric 97(4): 1055-64.

Pardo JE, Fernández E, Rubio M, Alvarruiz A, Alonso GL. 2009. Characterization of grape seed oil from different grape varieties (Vitis vinifera). Eur J Lipid Sci Technol 111: 188-193.

Pierron J-C. 2017. L'huile de pépins de raisin en France et dans le monde. OCL 24(5): D502.

Rombaut N, Savoire R, Thomasset B, Castello J, Hecke EV, Lanoisellè E. 2015. Optimization of oil yield and oil total phenolic content during grapeseed cold screw pressing. Ind Crop Prod 63: 26-33.

Sabir A, Unver A, Kara Z. 2012. The fatty acid and tocopherol constituents of the seed oil extracted from 21 grape varieties (Vitis spp.). J Sci Food Agric 92: 1982-1987.

Shi J, Yu J, Pohorly JE, Kakuda Y. 2003. Polyphenolics in grape seeds - biochemistry and functionality. J Med Food 6(4): 291-299.

Shinagawa FB, De Santana FC, Torres LRO, Mancini-Filho J. 2015. Grape seed oil: a potential functional food? Food Sci Technol 35: 399-406.

Tangolar SG, Özogul Y, Tangolar S, Torun A. 2009. Evaluation of fatty acid profiles and mineral content of grape seed oil of some grape genotypes. Int J Food Sci Nutr 60: 32-39.

Teixeira A, Baenas N, Dominguez-Perles R, et al. 2014. Natural bioactive compounds from winery by-products as healthpromoters: a review. Int J Mol Sci 15: 15638-78.

Cite this article as: Kapcsándi V, Hanczné Lakatos E, Sik B, Linka LÁ, Székelyhidi R. 2021. Characterization of fatty acid, antioxidant, and polyphenol content of grape seed oil from different Vitis vinifera L. varieties. OCL 28: 30. 